\section{AMERICAN ASTRONOMY.}

$I^{\mathrm{N}}$ $\mathrm{N}$ the year 1840 the Dana House Observatory of Harvard College was established by the aid of public funds and private subscription, with William Cranch Bond as director. It was not the first college observatory in America, and other eminent American astronomers had lived earlier in the century, but the date may be taken as the beginning of systematic astronomical observation in the Western continent. The U.S. Naval Observatory was established in 1844 , and the present Harvard Observatory founded, largely by generous help from private benefactors, in 1846 . Other institutions of the period might be named where the science of astronomy of position was pursued, and this, with the splendid work on planets, satellites, comets, asteroids, nebulæ, and the astronomy of the solar system generally done at Harvard by W. C. Bond and G. P. Bond, and afterwards by Winlock, is to be considered representative of the astronomy of the United States in the succeeding forty years. The accession of the late Prof. E. C. Pickering to the directorate of the Harvard Observatory in 1877 marks the beginning of the astronomical era in which we now live. Spectroscopy, stellar physics, and stellar statistics are the principal features. Prof. Pickering's work was stellar photometry on a wholesale scale. Stellar spectroscopy and the determination of the radial velocity of stars by its means had been begun by Huggins in 1864 ; the photographic plate came into general use as an adjunct to the astronomer's equipment in the decade $1880-90$, and these three items have formed the basis of the work of the American observatories of recent creation. The Lick Observatory, with the 36 -in. telescope, was completed in 1887 at the expense, as everyone knows, of an American business man. The Yerkes Observatory came into existence in 1897 , and the observatory at Mount Wilson' in 1904. 'These things are recalled at this moment because, during the past week, English astronomers have been gratified by: a visit from a delegation of astronomers from across the Atlantic who were on their way to take part in the establishment of an International Astronomical Union at a conference now being held in Brussels (July $18-28$ ).

At a meeting of the Roval Astronomical Society on July II, specially arranged for the purpose, the visitors spoke in turn of the work on which they are each engaged, and the contrast between the astronomy of to-day and of sixty years ago is apparent. The absolute magnitude of a star or its actual luminosity independent of its distance is now a commonplace, and forms the subject of many investigations. Certain peculiarities of spectrum have been correlated with the absolute magnitude in cases in which the latter is known, and, generalising from this, a method has been devised for finding from the spectrum the absolute magnitude, and therefore the parallax, of stars. Prof. W. S. Adams, to whom this conception is due, was constrained to say that the data on which his first list of parallaxes was based are capable of improvement, but this research is as yet in its early stages. Dr. Seares, also of Mount Wilson, has devised new photographic methods for determining the colours of stars, and a correlation between colour, spectral type, and absolute magnitude is being established. Prof. Benjamin Boșs, of the Dudley Observatory, whose name is associated more with geometrical astronomy than with physical, had some interesting facts to tell about the difference in direction of motion of the classes of stars known as the Giant and Dwarf, which is a distinction depending on luminosity.

Dr. Schlesinger, of Allegheny, and Prof. Joel Stebbins gave details of their work in determining the variation of brightness of variable stars, the method NO. 2594 , VOL. IO3] of the photo-electric cell used by the latter being a very recent adaptation of physics to astronomy not unknown in England; whilst Prof. Campbell, director of the Lick Observatory and president of the delegation, refrained from speaking of his well-known observations of radial velocity, but told his audience of the observations of the Lick Observatory party on the occasion of the eclipse of June 8, IgI8. An attempt was made to detect the Einstein effect, or a light-displacement effect from any cause, by comparison of a photograph of the stars round the sun with a photograph of the same field in the night sky, but the comparison failed to show any displacement of this nature. It is regrettable that the Harvard Observatory was not represented owing to the recent death of Prof. E. C. Pickering.

This brief sketch of the proceedings at this meeting is sufficient to show the trend of modern astronomy. It was impressing to see so many men, comparatively young, who are devoting themselves to abstract science. That there is similar progress on this side of the Atlantic reference to recent volumes of the Monthly Notices will show. Here, as counterpart to the brilliant invention of new methods of attack by observation above recorded, we have development by mathematical theory and the statistical discussion of results.

\section{THE MUSEUMS ASSOCIATION.}

$\mathrm{HE}$ thirtieth annual conference of this association, held at Oxford on July 7 -Io, under the presidency of Sir Henry Howonth, showed the return of peace conditions in a particularly large attendance. An important discussion was opened by Mr. E. E. Lowe on a recent recommendation by the Adult Education Committee of the Ministry of Reconstruction that the control of municipal museums (including art galleries) should be transferred to the local education authority. While this recommendation was supported by two officials of the Board of Education, who spoke in their private capacity, it was opposed by all the museum curators and by several members of museum committees, some of whom also served on education committees. Though museum authorities are, as they long have been, anxious to co-operate fully and intimately with schools and other educational institutions, they feel that many of their important functions cannot properly be described as educational, and they deprecate any form of control that would obscure this fact. On the other hand, they would welcome assistance and inspection by a separate museum department that should link up all the museums of the country and be directed by men familiar with museum work. A special committee was appointed to draw up a statement on behalf of the museums, and, if possible, to arrange conferences with the Government Departments concerned.

For some years the association has been trying to induce British manufacturers to provide for museum purposes glassware of a quality equal to that previously procurable only from Germany. Under war conditions no great success has attended its efforts, but Messrs. Standley Belcher and Mason, Ltd. of Birmingham, now submitted a small flatsided jar which appeared suitable. Trial orders were solicited, and, to attain a reasonable price, it is important that museums and laboratories should support the association in this matter. Communications may be addressed to $\mathrm{Mr}$. E. E. Lowe, Leicester Museum. In this connection it was of interest to learn from Mr. Renouf, of Rothesay, that when he wanted some trimmed glass squares he was told that there was no glass-planing machine in Great Britain. There are 